\title{
Developing Communication Book for Schizophrenia in Aceh: Prospects and Challenges
}

\author{
Maya Khairani ${ }^{1}$, Rizanna Rosemary ${ }^{2}$, Risana Rachmatan ${ }^{3}$, Lely Safrina ${ }^{4}$ \\ 1,3,4 Department of Psychology, Faculty of Medicine, \\ Universitas Syiah Kuala, Banda Aceh-Indonesia \\ ${ }^{2}$ Department of Communication Studies, Faculty of Social and Political Sciences, \\ Universitas Syiah Kuala, Banda Aceh-Indonesia \\ e-mail: *khairani.maya@unsyiah.ac.id
}

Received: 22 $2^{\text {th }}$ March 2021/Revised: $9^{\text {th }}$ July 2021/Accepted: $28^{\text {th }}$ July 2021

\begin{abstract}
The lack of media information about Schizophrenia in Aceh explains caregivers' limited understanding of mental disorders. Research on patient discharge systems found that communication media about Schizophrenia were still limited, mostly in the form of posters, flyers, or booklets. There was no specific information about the mental illness needed by the family or caregivers after the patient's discharged from the hospital. This study aims to develop and test a communication medium that can support the recovery process of post-discharge patients from the Mental Health Hospital or Rumah Sakit Jiwa (RSJ) in Aceh. This action research was carried out through focus group discussions (FGDs), interviews, and surveys to health practitioners (mental health nurses, psychiatrists, psychologists, community leaders) and family or caregivers of Patients with Schizophrenia (PWS). The study found that messages about Schizophrenia which are developed through a community-based approach are likely to be better accepted than the expert-led information.
\end{abstract}

Keywords: community-based approach, media education, indonesia, schizophrenia

Abstrak. Minimnya media informasi tentang Skizofrenia di Aceh menjelaskan masih terbatasnya pemahaman para tenaga kesehatan dan keluarga tentang kesehatan jiwa. Penelitian tentang sistem pemulangan pasien dengan gangguan jiwa (ODGJ) menemukan bahwa media komunikasi tentang Skizofrenia masih sangat kurang, hanya berbentuk poster, pamflet, atau buku saku. Belum adanya informasi spesifik tentang kesehatan jiwa yang dibutuhkan oleh para tenaga kesehatan di Rumah Sakit, maupun keluarga dengan pasien gangguan jiwa setelah diperbolehkan pulang ke rumah dan melakukan rawat jalan. Penelitian ini bertujuan untuk mengembangkan dan menguji sebuah media komunikasi (Buku Komunikasi) yang dalam mendukung proses penyembuhan pasien yang dipulangkan untuk dirawat di rumah. Pengumpulan data dalam pelitian aksi ini dilakukan melalui diskusi kelompok terfokus (FGD), wawancara, dan survei dengan tenaga/praktisi kesehatan, perawat, keluarga, dan anggota masyarakat setempat. Penelitian aksi ini menemukan bahwa pengembangan informasi/pesan tentang skizofrenia yang dilakukan melalui pendekatan berbasis masyarakat lebih diterima oleh tenaga kesehatan dan keluarga, dibandingkan dengan informasi yang disampaikan langsung dari para ahli.

Kata kunci: pendekatan berbasis komunitas, media edukasi, indonesia, skizofrenia 
Schizophrenia is a very complex mental disorder and is even described as a combination of various diseases affecting 20 million people worldwide (Schizophrenia Society of Canada, 2003; WHO, 2019). Data on People with Schizophrenia (PWS) or Orang dengan Skizoprenia (ODS) in Indonesia who are shackled within the last three months counted for about $31.1 \%$ of the population in the urban area, and $31,8 \%$ in the rural area. Moreover, early intervention for mental health patients remains limited, especially in the area with low mental health resources (Sebayang, et al, 2018; Good, et al, 2019). Less attention is given to the human rights aspect of the patient with mental disorder to have a proper and dignified treatment both at home and in the community (Irmansyah, 2009).

Aceh ranks fourth for the province with a high prevalence of PWS (Kemenkes, R.I, 2018). Aceh is an area that is often associated with the conflict and the 2014 tsunami disaster which later had a tremendous psychological impact on the people of Aceh. This is evidenced by data from the Aceh Provincial Health Office in 2010 which shows a significant increase in mental disorders with the highest number of schizophrenia cases, as much as $55.33 \%$. Schizophrenia is a serious psychotic disorder that requires ongoing treatment. In Aceh, 53.3\% of people with mental disorders receive treatment and are not neglected (Indrayani \& Wahyudi, 2019), meaning that $46.7 \%$ still need attention from their families and the government.

The mental health hospital or known as Rumah Sakit Jiwa (RSJ) Aceh provides care and treatment for mental patients, including those with schizophrenic. A high incidence of mental disorders cases in Aceh has caused a hospital in the stage of overcapacity to treat patients at the RSJ Aceh-an average of 600 people per day needed treatment in the province's primary mental health institution. Ideally, RSJ Aceh can only accommodate 300 patients per day. Mawarpury et al. (2014) study showed other problems that arose in the process of discharging patients from the hospital to be further treated at home. And before the patient leaves the hospital, the patient's family needs to be informed about the availability of drugs, the location of public health services, and 
the patient's needs for clothing, money, and housing, and planning for this will be obtained from resources in the community where the patient lives.

But the process of discharging patients from RSJ Aceh is not as ideal as it should be. The significant issue was about communication between the mental health care institutions and the family or community of PWS. In other words, lack of effective communication occurs between people or staff at RSJ Aceh, the provincial hospital (Rumah Sakit Umum Daerah-RSUD, and primary health care or Pusat Kesehatan Masyarakat (puskesmas), and family with members experiencing Schizophrenia. In reality, discharge planning is only done by documenting patient's resumes as they leave the hospital (for example, information such as interventions that were given during hospital care).

The burden that schizophrenia causes are not only on PWS but also on the family (Hou, Ke, Su, et al., 2008). For instance, some patients have daily activities such as trade, selling groceries, and other daily goods, but people in the community are reluctant to buy from their shop. People are afraid of getting into contact with PWS illness. This shows that people's understanding of schizophrenia mental disorders is still very minimal. The emergence of stigma not only on PWS but also on their families shows that the community has not been well-educated about this non-communicable disease-NCD (Schizophrenia Society of Canada, 2003; Sebayang et al., 2018). According to Mawarpury et al. (2014), several problems occurred such as when the patient is being treated, the family rarely visits the patient. This would be an obstacle for health workers in the RSJ to educate the patient's family. At the puskesmas level, the problem that arises is that there is a difference in the administration of drugs to patients with the drugs that patients receive when being treated at the RSJ. Meanwhile, at the community level, there is a lack of public knowledge about mental disorders and the government's lack of effort in educating the public about these issues.

According to Rahmadiana's study (2013), health promotion activities need to have strategies on how to deliver material in health promotion activities and selecting the right media for promotion. This is following the research carried out by Rachmatan et al. (2015) which explore the issue of health promotion about Schizophrenia in 
two Puskesmas at the Aceh Besar district-Kuta Baro and Lhoknga; that the guidelines on mental health promotion are not yet standardized, because health promotion media are made independently by health workers in the form of brochures and posters, where the content and visual appearance are never updated. Mental health promotion media is less attractive when compared to other health promotions such as breastfeeding or dengue fever. Health workers who carry out mental health promotions are also not equipped with adequate knowledge about the mental health problems they handle.

The way of delivering mental health information was still carried out through a conventional approach, such as one-way communication or counseling, called penyuluhan. Moreover, the media promotion to distribute information about mental health are plain, simple, and remains limited in number (2015). The significant findings drive these researchers to further develop information materials about Schizophrenia and effective media communication that may add to the needs and inadequacy of the current health communication interventions in both puskesmas.

A large number of studies have demonstrated the feasibility and effectiveness of carrying out a community-based approach in the issue of mental health especially in low-middle income countries, such as India (Chatarjee et al., 2003; Balaji et al., 2012), and in Indonesia (Muchlisin \& Pratiwi, 2017; Puspitosari, et.al., 2019; Suryani, et.al., 2011; Susanti et.al., 2020). For instance, Suryani, et.al. (2011) identified, mapped, and treated the clinical features of mentally ill people, who had been isolated and restrained by family and community members as a result of a functional failure of the traditional medical, hospital-based mental health model currently practiced in Indonesia. They concluded that the development of a community-based, culturally sensitive, and respectful mental health model can serve as an optimum promoter of positive mental health outcomes. Puspitosari et al. (2019) found that Community Based Rehabilitation (CBR) is effective for improving the quality of life of people with schizophrenia in the community.

This approach needs to incorporate a cultural-religious perspective to gain community trust as well as applying local wisdom in the messages to obtain people's acceptability of the information given through the communication platforms. 
(Darmastuti et al., 2016; Darmastuti et al., 2018; Hastuti et al., 2020). The communitybased approach enables the government to determine effective messages that are welltargeted according to the needs and expectations of the community, as the main beneficiaries of the health information. By applying local traditions and wisdom that are close to the need of the community is an effective way to assist in their behavioral change (Rosemary, 2020). A module to screen post-partum depression among pregnant women and breastfeeding mothers has been developed through a community-based approach (Sebayang et al., 2018), however, there is no specific communication medium found developed through a community-based approach that allows health practitioners and caregivers to monitor PWS after being discharged from the hospital.

Applying the community-based approach, this study developed a "communication book" which is important as a communication medium between health professionals and patient's family (PWS), especially to assist them with the instructions of the recovery process after the patient is discharged from the RSJ. It is expected that family and caregivers at home will have full support and responsibility to help the patient after being discharged from the hospital. This "communication book" aims also to provide the family with daily activities that can be carried out by the patient at home through their supervision. The objective of this research action is to develop effective media communication that is based on the needs of the family to help and support the family member with PWS for post-discharge recovery.

\section{Method}

This action research was conducted in Banda Aceh, Aceh Province, and the project was carried out within eight months. This study applied a qualitative approach with a case study design. A case study is an in-depth study of a particular situation which used to narrow down a very broad field of research into one easily researchable topic (Brodsky et al., 2016).

\section{Research Participants}

There were many participants involved in this research. Two health professionals and two staff in charge of mental health disorders from Puskesmas Kuta Baro and 
Lhoknga were interviewed on the problem definition stage. Then, six mental health nurses from six Puskesmas participated in FGD, three caregivers of patients with schizophrenia, and three community and religious leaders were interviewed in followup action after FGD. In the last stage, three experts were involved in FGD to review the content of the communication book.

\section{Research Instrument}

We used a simple questionnaire to gather information about the need for a communication book. The questionnaire consisted of 10 questions for caregivers and community/religious leaders. We add one number for mental health nurses to ask about the availability of a communication book for PWS. For three experts we asked them to fill the validation questionnaire related to the communication book.

\section{Research Procedure}

This research was carried out through the following stages (Prawitasari, 2011). First, Problem Definition. The action research started with gaining information from the field by observing the two puskesmas and doing interviews with the health professionals and staff in charge of mental health disorders in health care services. During interviews and observation at both Puskesmas Kuta Baro and Lhoknga.

Second, Fact findings. This stage refers to collecting data from the field, which is information obtained from the FGD which was carried out with six female mental health nurses from six puskesmas (Lampulo, Meuraxa, Batoh, Ulee Kareng, Banda Raya, and Baiturrahman) located at the Aceh Besar district. The FGD aims to elicit information from the health professional about the real condition of dealing with a family who has a member with PWS within their worksites. Furthermore, follow-up interviews were carried out with three caregivers of PWS. To gain insights from the community, we interviewed three males representing the community and religious leaders where the family with PWS resides and within the six working areas of the puskesmas. The purposes of both interviews and FGDs are to collect information related to Schizophrenic disorders derived from people's opinions and experiences that needed to be included in the communication book. After the interviews and FGDs, each informant is given and 
asked to answer the short survey consisting of questions about the significance of the communication media for Schizophrenia.

Third, The Determination of Objectives. In this stage, researchers developed content of the "communication book", including guideline activities that can be used by the patient's family at home post-discharge recovery. This stage is followed by the Action Process. At this stage, all information for the "communication book" is transferred in an updated layout. This activity involved two male graphic designers to design and translate some of the words (terminology) and concepts from the discussion and interview transcripts into simple-lay language that are visually appealing and easy to understand for both health professionals and family with PWS.

The last stage is Evaluation. The complete printed "Communication Book" is further tested both for its visibility (appearance) and content through a logical analysis procedure and expert review. The experts involved in the book review process are three experts in the field of mental health (psychiatrists, psychologists, and mental health nurses) who provide an overview of five indicators of the contents of the book. The five indicators include the value of representative, relevance, level of importance, clarity, and bias (subjectivity).

Diagram 1.

Stages of Developing Media Education for Schizophrenia Drawing from Prawitasari's Research Action Framework

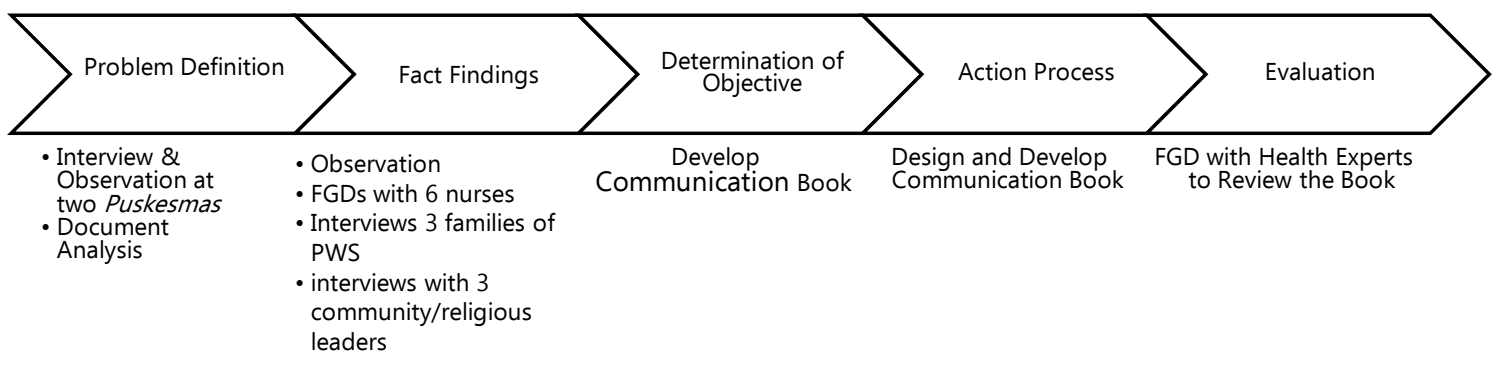

\section{Data Analysis}

We analyzed documents and relevant literature from the Puskesmas and RSJ. Findings from the interviews, FGDs, and observations process at stage one was used for developing the research instruments-interview guides, simple questionnaires, and FGD guidelines. Our analysis was also based on reviews from experts within a related 
field, such as psychiatry and health communication. Data found from stage two were analyzed and used to develop the communication book.

\section{Result}

Based on the stages through which several things found in this study can be identified as follows:

\section{Problem definition}

Communication book to connect health professionals with family/caregivers

The study found that health professionals particularly working at Puskesmas need a medium that can connect them to the family or caregivers of the PWS. The media enable a two-way interaction and communication between the health professional and family/caregivers to discuss how to take care of patients with mental illness at home. The research team agreed to provide and developed a connecting book and called it the "Communication book or handbook." Drawing from the first stage, research instruments for data collection are developed.

\section{Fact findings}

\section{Concise information and handy}

Audio-recorded data derived from the interviews, observation, and focus group discussions process at stage two are professionally transcribed and analyzed in themes and presented in the form of narratives. Document analysis is used to provide evidencebased thematic analysis. Moreover, the survey indicates that all informants are in consensus that a "Communication Book" is significant as media education and communication about Schizophrenia.

Based on the focus group discussion with six female nurses representing six puskesmas in Aceh Besar district, the research found that lack of information about Schizophrenia within their working area indicates the need for communication materials and media to inform and educate people about the mental health disorder which are subjected to high stigmatization rather than a feeling of empathy to help those with this severe mental illness. The health communication on this health mental issue is suggested 
to be in the form of a psychoeducation handbook or communication book about Schizophrenia. This module is aimed especially at the family or caregivers of the PWS. The module needs to consist of detail of the patient information - name, address, Schizophrenia status including symptoms, and medication, the information of the family or caregivers, and their contacts. The content about Schizophrenia includes a brief definition of hallucination followed by a concrete and simple example that is easy to understand. But from the discussion, all agreed not to put the image or picture of the patient on the personal information page to avoid stigmatization. The book also needs to include information about the health professionals in the Puskesmas or RSJ where the patients are referred to.

Some nurses suggested having the book consist of concise information about the patient's condition, the symptoms, the GP's diagnosis of the medication, and visitation schedules. These health professionals proposed that the information about the patient's status is in the form of a checklist. This template enabled them to read, confirm the information to the family, and checked and approved or not approved each information item which is expected to be used as information for other available health practitioners in charge of taking care of the patients. Interestingly, according to the nurses, the checklist information is usually required by staff at the RSJ. Their reason for close-ended statements in the book is because most of the staff are very busy and do have not much time to read the information in the form of narrative/stories or long-detail statements about the patient's condition.

Another important finding is that the book should make two copies, one kept by the puskesmas and the other with the family patient. Although arguments on this option arose with some nurses sad that it would cause another problem if the family was asked to keep the book and bring it along whenever they take the patient for consultation or treatment. Based on the health professional experiences, families tend to forget where they put the book at home or to bring it to the health care services; some of them lost the book during the first or second consultation/treatment visit after the patient being discharged. 


\section{Home-activities guidelines are necessary}

From the FGDs, it is found that other relevant information needs to be included in the "Communication Book" are ongoing therapy undertaken by the patient especially after being discharged from the hospital. Most importantly, the guideline activities can be carried out both at the Puskesmas or the patient's home. These activities or known as Terapi Kelompok Aktivitas (TAK) or group-activities therapy is necessary to continue the one being carried out in the hospital. The activities were carried out in the form of groups involving patients and nurses or health care and professionals. The TAK helps to reassure that patients are given a supportive environment that enables them to be wellrecovered. However, the health professional argued that the family tends to leave empty (blank) the TAK option in the book.

In addition, the book needs to have information (leave blank) about the history and an explanation of when, how, and why did the patient relapse and was admitted again to the hospital. According to the staff from the RSJ, usually, the family of PWS will contact the puskemas or RSJ whenever the patient started to be aggressive and screaming for no reason. This indicates that the family does not have information or knowledge of symptoms that the patient may exhibit when they relapsed. At the end of the book, there is a need to provide blank pages for health professionals and families of PWS to write feedback about the book and the intervention process.

\section{Appealing-Visual Book}

The majority of informants suggest the book is made from a good quality paper. They also believed in the importance to have some information used in the local Language-Acehnese and made it as simple as possible and easy to understand. All informants agreed to avoid the use of images, jargon, or taglines that tend to provoke stigma. The image or animation used for the book cover must not illustrate a GP giving treatment to the patients, which is commonly found in the conventional handbook or textbook. An informant suggests using an illustration of a happy family (adopting example from the handbook for mother-Kesehatan Ibu Anak (KIA). This strategy is important to convey the positive message about Schizophrenia, such as family support 
matters for PWS, not otherwise that may trigger stigmatization towards PWS and the family/caregivers.

\section{Determination of objective}

At this stage, the researcher compiles the text of the communication book according to the findings in the previous stage. Some of the points compiled are the cover, the title of the book, the patient's data page, the history of the disease, the diagnosis from the doctor, the type of therapy given, the schedule of visits, and the type of medication given to the patient. In addition, several pages of the book were inserted with information about the symptoms and the cause of schizophrenia, a graph of the patient's independence, things the patient can do, and the types of daily tasks that the patient can do.

\section{Action process}

At this stage, the researchers began to compile all information into a book called "Communication Book" containing guidelines and forms to fill in by health workers (from Puskesmas and RSJ) which are related to the patient's health condition, as well as information about schizophrenia disorders needed by the patient's family. This activity also involved two male graphic designers to design and translate some of the words (terminology) and concepts from the discussion and interview transcripts into simple-lay language that are visually appealing and easy to understand for both health professionals and family with PWS.

The following are some revised covers based on the various inputs we received:

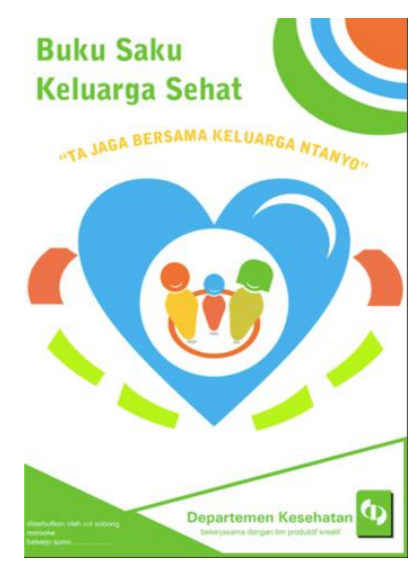

First design

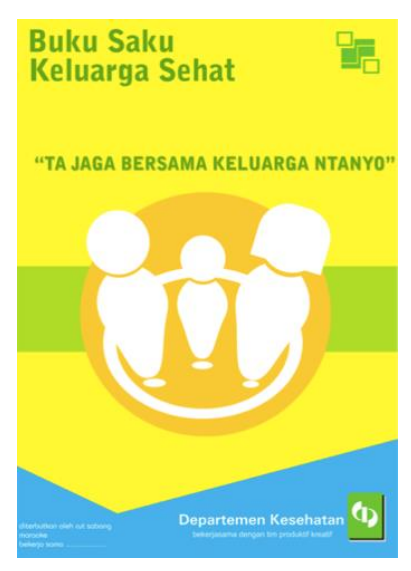

Second design 


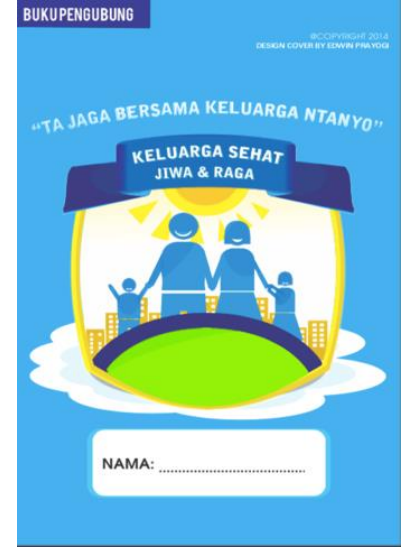

Third design

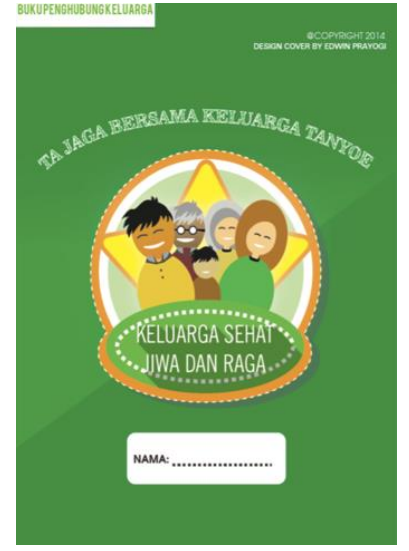

Fourth design

\section{Evaluation}

At this stage, the communication book is printed according to the design that has been agreed upon by the research team. The book was shown to three experts (psychiatrists, psychologists, and mental health nurses) for an expert review process. Some inputs from experts were: a) filling sheets for doctors, nurses, and psychologists on the same sheet so that control of patient management is easier,

b) the communication book contains pockets for patient treatment cards so that it makes the examination process easier if the patient is taken to the puskesmas or RSJ, c) information about drugs such as their function and side effects should be included, d) mention concrete examples of the patient's strange behavior when symptoms appear. The suggestions from the experts became meaningful input for the research team so that the book design also changed the expert review process.

\section{Discussion}

The five stages of developing effective media education for Schizophrenia has helped researchers not only to identify the main problems about Schizophrenia faced by health professionals in the field-Puskesmas and RSJ but also provide a feasible solution to solve the communication issues which became a significant barrier between health professionals and family/caregivers of the PWS. Through initial observation and interviews with health professionals at the two selected Puskesmas, the research found that midwives and nurses as health professionals faced difficulty in addressing messages 
about the importance of family and community supports to help and assists PWS after discharge from the hospital (RSJ).

Supported by previous studies and analyzing documents (media promotion materials) used by the Puskesmas, researchers concluded the need to develop a more effective media that may help and support health professionals to communicate about the mental health disorders to the people within their working area (Sebayang et al, 2018. Rosemary, 2020). Therefore, through FGDs consensus among other health professionals from various Puskesmas and interviews with family and respected people from the community, the researchers develop a 'Communication Book' aim to strengthen the connection and communication between health professionals and the family/caregivers of PWS. This community-based approach enables people to involve intensively in developing messages about how to prevent and treat Schizophrenia and what media platform that they think is feasible and effective to help the health practitioners, caregivers, and the family in taking care of patients with Schizophrenia in post-discharge recovery.

The 'Communication Book" in Indonesia is called Buku Penghubung was further reviewed by expertise in psychology, psychiatry, and medicine. The feedback from expertise helps researchers to revise and finalize the book. The book was printed in limited exemplars and given to RSJ and selected Puskesmas for trial.

During the second year of the project, the trial stage of the "Communication Book." While further study is required to explore and evaluate the effectiveness of the book provided by the health care institution, researchers found downsides of the "Communication Book" development process. The Buku Penghubung was found to be useful for health professionals at both the puskemas and RSJ, and they are very excited to use the book. However, through short visitation and conversation with two parents of PWS, it seems that they are less interested in the media intervention. The parents admitted understanding the function of the book, but some of them also believe that Schizophrenia is a result of a curse that cannot be cured; thus, they must accept and live with it. The notion of 'Schizophrenia as God's curse' was also found during the first stage of research. The information gained from midwives and nurses at the Kuta Baro 
puskesmas showing strong beliefs that the family and the community have about PWS because of a curse and can only be healed or cured through the traditional healer, namely dukun/tabib.

Even though this cultural context information was acknowledged as part of the problem during the identification process, it was not included in the book. People's belief and cultural view about the mental illness was undermined and suggest being less important than communication which was argued to be the main problem in the field. The research showed that $90 \%$ of the information developed in the book was derived from the discussion with the mental health nurses, while only $10 \%$ of information is based on dialogue with family or cadres of patients with PWS. Undervaluing people's beliefs and tradition may hamper their understanding and acceptance of novel ideas and solutions to communicate health issues. Therefore, there is a need to include family and caregivers of PWS in the review process of the "Communication Book."

\section{Conclusion}

Understanding the social practice that shapes the PWS and their family or caregivers' voices and experiences about Schizophrenia will help create avenues for better strategies when developing media intervention to educate and raise people's awareness about mental health disorders. The top-down approach from the government will not be effective if the community as the target of the message is not involved and their voices are not heard. Through dialogue with the community, the government and health practitioners can identify role models in society who can be involved as agents of health communicators or agents of change in society. Involving the community in the assessment of this Communication Book helps to better develop the existing media communication. Thus, the 'Communication Book' developed from this research action need to include and integrate specific social, cultural, and religious values relevant to people's belief and practice and their needs, desires, and expectations that will assist in addressing the message about the significance support from family and community to PWS. For further research, the effectiveness of this book also tests the user, in this case, as the caregiver of schizophrenia patients. 


\section{References}

Balaji, M., Chatterjee, S., Koschorke, M., Rangaswamy, T., Chavan, A., Dabholkar, H., ... \& Patel, V. (2012). The development of a lay health worker delivered collaborative community-based intervention for people with schizophrenia in India. BMC health services research, 12(1), 42.

Brodsky, A. E., Buckingham, S. L., Scheibler, J. E., \& Mannarini, T. E. R. R. I. (2016). Introduction to qualitative approaches. Handbook of methodological approaches to community-based research: Qualitative, quantitative, and mixed methods, 13-22.

Chatterjee, S., Patel, V., Chatterjee, A., \& Weiss, H. A. (2003). Evaluation of a community-based rehabilitation model for chronic schizophrenia in rural India. The British Journal of Psychiatry, 182(1), 57-62.

Darmastuti, R., Edi, S. W. M., \& Christianto, E. (2018). Model Literasi Media Untuk Anak-Anak Sekolah Dasar Dengan Menggunakan Multimedia Interaktif Berbasis Kearifan Lokal Masyarakat Salatiga. Jurnal ASPIKOM, 3(4), 635-649.

Darmastuti, R., Bajari, A., Martodirdjo, H. S., \& Maryani, E. (2016). Gethok Tular, Pola Komunikasi Gerakan Sosial Berbasis Kearifan Lokal Masyarakat Samin di Sukolilo. Jurnal Aspikom, 3(1), 104-118.

Irmansyah, I., Prasetyo, Y. A., \& Minas, H. (2009). Human rights of persons with mental illness in Indonesia: more than legislation is needed. International journal of mental health systems, 3(1), 14.

Good, B. J., Marchira, C. R., Subandi, M. A., Mediola, F., Tyas, T. H., \& Good, M. J. D. (2019). Early psychosis in Indonesia: reflections on illness and treatment. International Review of Psychiatry, 31(5-6), 510-522.

Hastuti, T. Setyowati, H. N., \& Rosemary, R. (2020). Rumah Gizi ‘Aisyiyah: Komunikasi Kesehatan dengan Pendekatan Agama-Budaya. Jurnal Komunikasi Global, 9(1), 141-161.

Indrayani, Y. A \& Wahyudi, T. (2019). Situasi Kesehatan Jiwa di Indonesia. Pusat Data dan Informasi Kementrian Kesehatan Republik Indonesia.

Kemenkes, R. I. (2018). Hasil Utama Riset Kesehatan Dasar Tahun 2018. Kementrian Kesehatan Republik Indonesia, 1-100.

Lewis, B., \& Lewis, J. (2014). Health communication: a media and cultural studies approach. Macmillan International Higher Education.

Mawarpury, M., Sulistyani, A., Karjuniwati., Sari, H., Rachmalia, Direzkia, Y., \& Pamungkas, S. R. (2014). Discharging mental health patients in Aceh: A preliminary study. Anima Indonesian Psychological Journal, 29, 95-102.

Muhlisin, A., \& Pratiwi, A. (2017). Community-based participatory research to improve primary mental health services. International Journal of Research in Medical Sciences, 5(6), 2524-2528. 
Nurbaya, N., \& Caninsti, R. (2014). Pengaruh promosi kesehatan fear arousing warning terhadap intensi mengonsumsi fried chicken pada siswa SD usia 9-11 tahun. Jurnal Psikogenesis, 2, 152-166.

Puspitosari, W. A., Wardaningsih, S., \& Nanwani, S. (2019). Improving the quality of life of people with schizophrenia through community-based rehabilitation in Yogyakarta Province, Indonesia: A quasi-experimental study. Asian journal of psychiatry, 42, 67-73.

Rachmatan, R., Khairani, M., Yulandari, N., Aprilia, E. D., \& Rosemary, R. (2015). Identifikasi program promosi kesehatan jiwa masyarakat Aceh Besar. Prosiding Seminar Nasional Kesehatan Mental dari Perspektif Kultural.

Rahmadiana, M. (2013). Program promosi kesehatan bagi anak-anak. Jurnal Psikogenesis, $1,116-129$.

Rosemary, R. (2020). Mengulik Lemahnya Komunikasi Kesehatan Pencegahan Covid19: Studi Kasus di Provinsi Aceh. Working Paper.

Sarafino, E. P. (1998). Health Psychology: Biopsychosocial Interactions (3rd edition). John Wiley \& Sons.

Sebayang, SK, Mawarpury, M, Rosemary, R. 260 million people and less than 1000 psychiatrists, Indonesia's mental health worker shortage. The Conversation. [accessed on 2 January 2020]. https://theconversation.com/260-million-people-and-lessthan-1000-psychiatrists-indonesias-mental-health-worker-shortage-104927

Suryani, L. K., Lesmana, C. B. J., \& Tiliopoulos, N. (2011). Treating the untreated: applying a community-based, culturally sensitive psychiatric intervention to confined and physically restrained mentally ill individuals in Bali, Indonesia. European archives of psychiatry and clinical neuroscience, 261(2), 140.

Susanti, H., James, K., Utomo, B., Keliat, B. A., Lovell, K., Irmansyah, I., ... \& Brooks, H. (2020). Exploring the potential use of patient and public involvement to strengthen Indonesian mental health care for people with psychosis: a qualitative exploration of the views of service users and cares. Health Expectations, 23(2), 377387. 